Brazilian Journal of Microbiology (2009) 40: 631-635

ISSN 1517-8382

\title{
OBTAINING PARTIAL PURIFIED XYLOSE REDUCTASE FROM CANDIDA GUILLIERMONDII
}

\author{
${ }^{1 *}$ Ester Junko Tomotani, ${ }^{2}$ Priscila Vaz de Arruda, ${ }^{1}$ Michele Vitolo, ${ }^{2}$ Maria das Graças de Almeida Felipe \\ ${ }^{1}$ Universidade de São Paulo, Escola de Farmácia, Departamento Bioquímica e Tecnologia Farmacêutica, São Paulo, SP, Brasil; \\ ${ }^{2}$ Universidade de São Paulo, Escola de Engenharia de Lorena, Departamento de Biotecnologia, Lorena, SP, Brasil.
}

Submitted: July 15, 2008; Returned to authors for corrections: September 25, 2008; Approved: May 03, 2009.

\begin{abstract}
The enzymatic bioconversion of xylose into xylitol by xylose reductase (XR) is an alternative for chemical and microbiological processes. The partial purified XR was obtained by using the following three procedures: an agarose column, a membrane reactor or an Amicon Ultra-15 50K Centrifugal Filter device at yields of $40 \%, 7 \%$ and $67 \%$, respectively.
\end{abstract}

Key words: Xylose reductase, Xylitol, Partial purification.

Xylitol is a valuable product, largely employed as a sweetener in food, dentistry and pharmaceutical formulations $(8,13)$. In spite of the natural occurrence of xylitol in fruits, its extraction is uneconomical (9). Besides a chemical process which is industrially applied, xylitol can be produced by a biotechnological means in which a strain of Candida guilliermondii is used. The yeast, as any pentose-fermenting or pentose-utilizing microorganism, has the xylose reductase in the cytoplasm, which catalyses the conversion of xylose into xylitol (2). Nevertheless, the xylose/xylitol conversion, through the fermentative process, presents, as limiting factors, the precise control of culture conditions $(\mathrm{pH}$, temperature, agitation, absence of cell inhibitors, etc.), expensive nutrients, huge water consumption and the type of process (13). As xylitol is a compound of high value, many studies have been done to establish the best condition to perform the biotechnological process (13). Xylose reductase is not available commercially despite the several studies found in the literature on the potential usage of xylose reductase as well as there being a description of downstream procedures regarding its separation from the yeasts (10). Consequently, the enzyme must be obtained by cultivating the yeast Candida guilliermondii - which is reported to be one of the most efficient xylitol producers $(3,4,7)$ - through an aerated batch process, previously established (11).

However, after the cell disruption and the removal of cell

*Corresponding Authors. Mailing address: University of São Paulo, Pharmacy School, Dept. Biochemical and Pharmaceutical Technology, Av. Prof. Lineu Prestes, 580, B.16, São Paulo, SP, Brazil.; E-mail: esterj@usp.br 
fragments, the xylose reductase has to be separated from the cell-free extract before using it in order to avoid the presence of xylitol dehydrogenase (another natural occurring enzyme in Candida genus). This enzyme catalyses the conversion of xylitol to xylulose, leading to the decreasing of the xylose/xylitol yield (4). The objective of this work was to separate xylose reductase (XR) from xylitol dehydrogenase to explore the maximal efficiency of XR on xylose/xylitol conversion in bioreactors.

Xylose reductase (EC 1.1.1.21) has a molecular weight (MW) of $36 \mathrm{kDa}$ and requires NADPH as cofactor $(4,5)$. Its use, either in a continuous or a discontinuous bioreactor, constitutes an alternative of economic interest regarding both the catalytic hydrogenation of pure xylose and the fermentation of the xylose present in lignocellulosic hydrolysates (obtained from sugar-cane bagasse, corn or rice straw, etc.) (1).

Xylose reductase was gotten from Candida guilliermondii which has been cultivated as follows (11): C. guilliermondii FTI 20037 was inoculated in the medium formulated with Dxylose $\left(30\right.$ g. $\left.\mathrm{L}^{-1}\right)$ and supplemented with $\left(\mathrm{NH}_{4}\right)_{2} \mathrm{SO}_{4}\left(2.0\right.$ g. $\mathrm{L}^{-}$ $\left.{ }^{1}\right), \mathrm{CaCl} .2 \mathrm{H}_{2} \mathrm{O}\left(0.1 \mathrm{~g} . \mathrm{L}^{-1}\right)$, and rice bran extract $(10 \% \mathrm{v} / \mathrm{v})$. The culture was maintained in a rotating shaker under an agitation of $100 \mathrm{rpm}$ at $30^{\circ} \mathrm{C}$ and $\mathrm{pH} \mathrm{5.5.} \mathrm{A} \mathrm{volume} \mathrm{of} \mathrm{the}$ yeast suspension containing $0.3 \times 10^{8} \quad{\text { cells. } L^{-1}}^{-1}$ (approximately 1 g. $\mathrm{L}^{-1}$ ) was used to inoculate a fermenter. The fermenter was filled with a synthetic medium, which consisted of xylose $\left(50\right.$ g.L $\left.\mathrm{L}^{-1}\right)$ supplemented with $\left(\mathrm{NH}_{4}\right)_{2} \mathrm{SO}_{4}$ (2.0 g. $\left.\mathrm{L}^{-1}\right), \mathrm{CaCl}_{2} .2 \mathrm{H}_{2} \mathrm{O}\left(0.1\right.$ g. $\left.\mathrm{L}^{-1}\right)$ and rice bran extract $(20$ g. $\left.\mathrm{L}^{-1}\right)$. The fermentation was performed in a batch process for $34 \mathrm{~h}$ at $30^{\circ} \mathrm{C}, \mathrm{pH} 5.5$ and an agitation of $200 \mathrm{rpm}$. The cells were harvested by centrifugation at $2700 \mathrm{x}$ g for $15 \mathrm{~min}$, and re-suspended in $0.1 \mathrm{~mol}$. $\mathrm{L}^{-1}$ phosphate buffer ( $\mathrm{pH}$ 7.2). The final suspension (15 g.. $\left.\mathrm{L}^{-1}\right)$ was stored in a freezer until further procedure.
The cells were suspended in a sterile solution containing a mixture of protease inhibitors $(2 \mathrm{mM}$ aminocaproic acid, 10 $\mathrm{mM} \beta$-mercaptoethanol, $1 \mathrm{mM}$ phenil-methil-sulphonylfluoride and $0.2 \mathrm{mM}$ EDTA). A suspension of $1.7 \mathrm{~mL}$ (containing $0.2 \mathrm{~g}$ cells $/ \mathrm{mL}$ ) was then mixed with $3.30 \mathrm{~mL}$ of phosphate buffer (0.1 M; pH 7.2) and submitted to disruption by $20-\mathrm{kHz}$ sonication in $1 \mathrm{~s}$ pulses for a period of $45 \mathrm{~min}$ (Disrupter VC-100; Sonics \& Materials, Newton, CT, USA). Afterwards, the cell fragments were removed by centrifugation $(6700 \mathrm{x} \mathrm{g}$ for $10 \mathrm{~min})$ at $4^{\circ} \mathrm{C}$. The clarified supernatant was used as source of xylose reductase (XR). The XR activity was determined spectrophotometrically (Beckman-Colter, model DU 640) at $340 \mathrm{~nm}$ at room temperature (12). One XR unit (U) was defined as the amount of enzyme which catalyzes the oxidation of $1 \mu \mathrm{mol}$ $\mathrm{NADPH} / \mathrm{min}$. Specific activities were expressed as U.mg ${ }_{\text {prot }}{ }^{-1}$. Protein concentration was determined by the Bradford assay using bovine serum albumin as a standard (BSA purchased from Sigma Chemical Co. - St. Louis, MO, USA).

The clarified supernatant was submitted to three procedures in order to attain the partially purified XR.

The first one was carried out as described previously by Kostrzynska et al. (6) where an agarose column was used ("green-19" purchased from Sigma Chemical Co. - St. Louis, MO, USA). An aliquot of the supernatant $(0.5 \mathrm{~mL})$ was poured into a $15 \mathrm{~mL}$ tube containing $0.5 \mathrm{mg}$ of agarose which was equilibrated previously with $3 \mathrm{~mL}$ of $50 \mathrm{mM}$ phosphate buffer ( $\mathrm{pH}$ 7.0) for 24 hours. The XR was eluted from the agarose with a $2 \mathrm{M} \mathrm{NaCl}$ solution. Afterwards, the enzyme activity and the protein concentration present in the eluate were measured.

The second procedure was consisted of a $10 \mathrm{~mL}$ membrane bioreactor (BMR- Bioengineering membrane reactor, Bioengineering AG, Wald, Germany), which was coupled with an UF-membrane (cut off of $50 \mathrm{kDa}$, purchased 
from Millipore - Bedford, MA, USA). An aliquot of $9.5 \mathrm{~mL}$ of the supernatant was poured into the reactor which was fed continuously with $10 \mathrm{mM}$ phosphate buffer $(\mathrm{pH}$ 7.2) at a feeding rate of $6.0 \mathrm{~h}^{-1}$ for 100 minutes. Samples were collected every 5 minutes. Both enzyme activity and the protein concentration were determined in each collected sample.

The third was based on an ultracentrifugation process. The supernatant obtained through the sonication and further centrifugation was diluted to $1: 4,1: 5$ and $1: 10(\mathrm{v} / \mathrm{v})$. A 10 $\mathrm{mL}$ of diluted sample was added into an Amicon Ultra-15 50K NMWL (Nominal Molecular Weight Limit) Centrifugal Filter device and centrifuged at $10.000 \mathrm{x} \mathrm{g}$ for 30 minutes at $4^{\circ} \mathrm{C}$. Subsequently, the filtrate was collected for further protein and XR activity determinations.

Table 1 shows the activities of $\mathrm{XR}$, the purification factor and the yield attained through the different processes for the partial xylose reductase purification.

The best result was attained when an ultracentrifugation process was applied (yield of $67 \%$ for the sample which was diluted to 1:10). According to the manufacturer, the Amicon Ultra Centrifugal Filter device design incorporates a Millipore Ultracel ${ }^{\circledR}$ regenerated cellulose low binding membrane which provides sample recoveries from dilute and complex sample matrices. The device is characterized by a nominal molecular weight limit which is its ability to retain molecules above a NMWL. By using the filter device, it is supposed to retain $\mathrm{XD}(63-87 \mathrm{kDa})(3)$, at the membrane and as a result, to recover XR $(36 \mathrm{kDa})$ at the bottom of the tube. The activity of XD was also determined to assure that the separation process was successful. By comparing the XR activities before and after the ultracentrifugation procedure, the yield of partial purification of XR for 1:4, 1:5 and 1:10 was $45.6 \%, 64.5 \%$ and $67.2 \%$ respectively (data not shown). Both the 1:10 and 1:5 dilutions showed a promising result; except for the first supernatant obtained after disrupting the cells, the activity of XD was not detected in any of the filtrated samples. According to the product information, solutes with a molecular weight close to the NMWL, may only be partially retained. The yield, therefore, might have been influenced by the presence of other proteins and other small impurities with similar molecular weight which competed with $\mathrm{XD}$ and kept the enzyme at the membrane. A better result would be achievable as long as the samples were more diluted or pre-purified before the ultracentrifugation.

Although the agarose column showed to be a specific way for purifying XR, as demonstrated by Kostrzynska et al. (6), the intense blue color of the eluted solution interfered sharply on the analytical determinations. In order to proceed with the $\mathrm{XR}$ activity and protein measurements, the solution might be highly diluted which would lead to a significant deviation on the accuracy of the analytical procedures.

By using the membrane bioreactor, the purification yield was calculated by the sum of XR activities of each collected sample. However, the XR activity was significantly detected only in the first five collected samples. In the subsequent samples, the XR activity measurement was almost undetectable because the solutions were highly diluted as a consequence of the specific feeding rate employed throughout the ultrafiltration procedure. Therefore, a further concentration of the samples might be necessary to measure, more precisely, the purification yield through this procedure.

The xylose reductase can be partially purified through the downstream procedure: disruption of the yeast cells by sonication in presence of protease inhibitors, followed by centrifugation (10000 x g for $30 \mathrm{~min}$ ) and ultracentrifugation through a $50 \mathrm{kDa}-\mathrm{UF}-m e m b r a n e$. It must be considered that the final enzyme solution, prepared as described, does not present xylitol dehydrogenase activity which catalyses the 
undesirable conversion of xylitol into xylulose. Furthermore, it circumvents an interference of xylitol dehydrogenase (EC
1.1.1.9) $(\mathrm{XDH})$ when a fermentation process is chosen despite its regenerating NADPH (4).

Table 1. Partial purification of xylose reductase through the agarose column, membrane bioreactor and ultracentrifugation process.

\begin{tabular}{lcccc}
\hline Procedures & $\begin{array}{r}\text { Specific activity } \\
(\mathrm{U} / \mathrm{mg} \text { protein })\end{array}$ & $\begin{array}{c}\text { Total activity } \\
(\mathrm{U})\end{array}$ & $\begin{array}{c}\text { Purification } \\
\text { factor }\end{array}$ & $\begin{array}{c}\text { Yield } \\
(\%)\end{array}$ \\
\hline Agarose Column & $25.3 \times 10^{-4}$ & $12.4 \times 10^{-2}$ & 2.84 & 39.6 \\
$\begin{array}{l}\text { Membrane bioreactor } \\
\text { Ultracentrifugation }\end{array}$ & $27.2 \times 10^{-4}$ & $2.29 \times 10^{-2}$ & 3.05 & 7.26 \\
process $(1: 10)$ & $12.2 \times 10^{-3}$ & $21.3 \times 10^{-1}$ & 13.7 & 67.2
\end{tabular}

The total and specific activities of xylose reductase before undergoing those procedures were respectively $3.17 \times 10^{-2} \mathrm{U}$ and $8.92 \times 10^{-4} \mathrm{U} / \mathrm{mg}$ of protein. The purification factor was defined as the ratio between the specific activity of purified xylose reductase and the specific activity of xylose reductase before the treatment.

An alternative and a promising approach of the xylosexylitol bioconversion would be regenerating the cofactor. As a perspective that follows from the presented achievement, the bioconversion of xylose to xylitol using glucose 6phosphate dehydrogenase as an auxiliary enzyme to reduce the cofactor NADP to NADPH, has already been evaluated. Thus, the solution containing XR and deprived of XD would be useful for carrying out the xylose/xylitol conversion in a batch or continuous bioreactor. Such an approach might be an alternative for the chemical synthesis and the fermentation process which are largely used currently.

\section{ACKNOWLEDGEMENTS}

This research was supported by Fapesp (Fundação de Amparo à Pesquisa do Estado de São Paulo). The authors gratefully appreciate a kind and a valuable assessment made by Philip Barsanti.

\section{Obtenção de xilose redutase de Candida guilliermondii parcialmente purificada}

A bioconversão enzimática da xilose em xilitol pela xilose redutase (XR) é uma alternativa para as vias química e microbiológica. Avaliou-se a purificação parcial da XR, utilizando os três seguintes procedimentos: uma coluna de agarose, um reator com membrana ou tubos de ultracentrifugação Amicon Ultra-15 50K, com rendimento de $40 \%, 7 \%$ ou $67 \%$, respectivamente.

Palavras-chave: Xilose redutase, Xilitol, Purificação parcial

\section{REFERENCES}

1. Alves, L.A.; Felipe, M.G.A.; Almeida e Silva, J.B.; Silva, S.S.; Prata, A.M.R. (1998). Pretreatment of sugar cane bagasse hemicellulose hydrolysate for xylitol production by $C$. guilliermondii. Appl. Biochem. Biotechnol. 70 (2), 89-98.

2. Byron, CH.; Chu, HL. (2006). Investigation of the role of a conserved glycine motif in the Saccharomyces cerevisiae xylose reductase. Curr. Microbiol. 53, 118-123. 
3. Häcker, B.; Habenicht, A.; Kiess, M.; Mattes, R. (1999). Xylose utilization: cloning and characterization of the xylose reductase from Candida tenuis. J. Biol. Chem. 380, 1395-1403.

4. Handumrongkul, C.; Ma, D.P.; Silva, J.L. (1998). Cloning and expression of Candida guilliermindii xylose reductase gene (xyll) in Pichia pastoris. Appl. Microbiol. Biotechnol. 49, 399-404.

5. Kavanagh, K.L.; Klimacek, M.; Nidetzky, B.; Wilson, D.K. (2003). Structure of xylose reductase bound to $\mathrm{NAD}^{+}$and the basis for single and dual co-substrate specificity in family 2 aldo-keto reductases. Biochem. J. 373, 319-326.

6. Kostrzynska, M.; Sopher, C.R.; Lee, H. (1998). Mutational analysis of the role of the conserved lysine-270 in the Pichia stipitis xylose reductase. FEMS Microbiol. Lett. 159 (1), 107-112.

7. Lee, H. (1998). The Structure and Function of Yeast Xylose (Aldose) Reductases. Yeast. 14, 977-984.

8. Lima, L.H.A.; Felipe, M.G.A.; Torres, F.A.G. (2003). Reclassification of Candida guilliermondii FTI 20037 as Candida tropicalis based on molecular phylogenetic analysis. Braz. J. Microbiol. 34 (1), 96-98.

9. Murthy, G.S.; Sridhar, S.; Sunder, M.S.; Shankaraiah, B.; Ramakrishna,
M. (2005). Concentration of xylose reaction liquor by nanofiltration for the production of xylitol sugar alcohol. Sep. and Purif. Technol. 44, 205-211.

10. Rawat, U.B.; Rao, M.B. (1996). Purification, kinetic characterization and involvement of tryptophan residue at the NADPH binding site of xylose reductase from Neurospora crassa. Biochim. Biophys. Acta. 1293, 222-230.

11. Rodrigues, R.C.L.B; Sene, L.; Matos, G.S.; Roberto, I.C.; Pessoa Jr, A.; Felipe, M.G.A. (2006). Enhanced xylitol production by precultivation of Candida guilliermondii cells in sugarcane bagasse hemicellulosic hydrolysate. Curr. Microbiol. 53, 53-59.

12. Sene, L.; Felipe, M.G.A; Silva, S.S.; Vitolo, M. (2001). Preliminary kinetic characterization of xylose reductase and xylitol dehydrogenas extracted from Candida guilliermondii FTI 20037 cultivated in sugarcane bagasse hydrolysate for xylitol production. Appl. Biochem. Biotechnol. (91-3), 738-743.

13. Silva, S.S.; Mussatto, S.I.; Santos, J.C.; Santos, D.T.; Polizel, J. (2007). Cell immobilization and xylitol production using sugarcane bagasse as raw material. Appl. Biochem. Biotechnol. 141, 215-228. 